\title{
Financing Food Assistance: Options for the World Food Programme to Save Lives and Dollars
}

\section{Vijaya Ramachandran, Benjamin Leo, and Owen McCarthy}

\section{Abstract}

The World Food Programme has world-class logistics, but its ability to manage financial risk is extremely limited. The WFP procures 100 percent of its food through spot markets, which subjects it to substantial commodity and transport price risks and significant delays delivering food. Relying on reactive emergency appeals and on donors that tend to earmark contributions and make commitments one year at a time only adds to operational inflexibility and uncertainty.

On the other hand, much of the WFP's operations are fairly predictable, especially the countries served and the volume of food delivered. The Programme should consider implementing a targeted hedging pilot strategy focused on several chronically food vulnerable countries. Several risk-management instruments are available, such as physical call options, forward contracts, and futures contracts. Key benefits of such hedging strategies would include greater financial predictability, the potential for improved delivery times, and increased local and regional trade that could build on the WFP's Purchase for Progress initiative.

Changes from donors would also help the WFP shore up its operations. Greater commitments of untied cash donations from the United States and other major donors can provide the WFP significant operational flexibility to execute prudent financial management operations. Donor contributions to the proposed Food Security Trust Fund at the World Bank would further support WFP hedging operations. This fund could provide a financial guarantee or modest credit line which would enable the WFP to enter into commodity derivative contracts for up to one year in the future. 


\title{
Financing Food Assistance: Options for the World Food Programme to Save Lives and Dollars
}

\author{
Vijaya Ramachandran \\ Benjamin Leo \\ Owen McCarthy
}

\begin{abstract}
Vijaya Ramachandran is senior fellow at the Center for Global Development. Benjamin Leo is a visiting fellow at the Center for Global Development, former Director for African Affairs at the National Security Council and senior staff member of the U.S. Department of Treasury. Owen McCarthy is a research assistant at CGD. The authors are very grateful to WFP staff, and to Nancy Birdsall, Owen Barder, Julie Dana, Kim Elliott, Alan Gelb, Gawain Kripke, Todd Moss, Liliana Rojas-Suarez, John Simon and Peter Timmer for helpful comments and suggestions. We are grateful to AusAid for financial support. The authors are solely responsible for any errors in fact or judgment.
\end{abstract}

CGD is grateful for contributions from the Australian Agency for International Development in support of this work.

Center for Global Development 1800 Massachusetts Ave., NW Washington, DC 20036

202.416.4000

(f) 202.416 .4050

www.cgdev.org
Vijaya Ramachandran, Benjamin Leo, and Owen McCarthy. 2010. "Financing Food Assistance: Options for the World Food Programme to Save Lives and Dollars." CGD Working Paper 209. Washington, D.C.: Center for Global Development. http://www. cgdev.org/content/publications/detail/1424053

The Center for Global Development is an independent, nonprofit policy research organization dedicated to reducing global poverty and inequality and to making globalization work for the poor. Use and dissemination of this Working Paper is encouraged; however, reproduced copies may not be used for commercial purposes. Further usage is permitted under the terms of the Creative Commons License.

The views expressed in this paper are those of the author and should not be attributed to the board of directors or funders of the Center for Global Development. 


\section{EXECUTIVE SUMMARY}

\section{Key Background Points:}

(1) While the WFP has a world class logistical capability, its financial risk management capacity is extremely limited.

(2) 100 percent of WFP food procurement is executed through spot markets. This exposes it to substantial commodity and transport price risk as well as significant food delivery delays.

In 2008, the WFP experienced a 40-50 percent budget gap due to sharp commodity and transport price increases.

$>$ The net impact was dramatically higher per capita food assistance costs and sustained levels of hunger and malnutrition in some parts of the developing world.

(3) The WFP has limited flexibility to actively manage price risks. This is due to its: (i) reactive and unpredictable revenue mobilization model (relying on emergency appeals); (ii) lack of multi-year donor contribution commitments; and (iii) restricted donor contributions (in-kind transfers or program earmarks).

$>$ Unrestricted cash contributions typically account for less than 10 percent of the WFP's total budget.

(4) A significant portion of the WFP's operations are fairly predictable-both in terms of countries and food delivery volumes.

During the 2000s, ten countries consistently accounted for the majority of WFP assistance. While assistance levels (in dollar terms) did fluctuate, there was still significant consistency.

(5) Five commodities that account for over 60 percent of WFP procurement are available on international commodity exchanges (ex - South African Futures Exchange or SAFEX).

CGD Proposal: The WFP and its Board should consider implementing a targeted hedging pilot focused on several chronically food vulnerable countries. Our paper 
outlines a highly conservative decision making methodology for consideration. There are several risk management instruments available for WFP operations, such as: (i) physical call options; (ii) forward contracts; and (iii) futures contracts. All instruments are utilized widely for risk management purposes. Several commodity exchanges offer sufficient commodity coverage and market depth to prevent market distortion effects (ex - SAFEX). Key benefits include: (i) greater financial predictability; (ii) the potential for improved delivery times; and (iii) increased local and regional trade, building upon the WFP's Purchase for Progress initiative.

Potential for U.S. and Other Rich Country Leadership: As the WFP's largest donor, the U.S. is uniquely positioned to lead reform efforts that will dramatically increase operational effectiveness and efficiency. There are several options, such as:

(1) Institutional Pressure: The U.S. and other major donors could press the WFP Board to launch the proposed hedging pilot as a first step. This approach likely should be pursued in partnership with several other WFP reform champions.

(2) WFP Untied Cash Contribution: A commitment of untied cash donations could provide the WFP significant operational flexibility to execute prudent financial management operations. The U.S. and other rich countries could instruct WFP management to utilize these cash resources specifically for the proposed hedging pilot.

(3) World Bank Food Security Trust Fund: Planned donor contributions to the proposed Food Security Trust Fund could support WFP hedging operations. Specifically, the World Bank Trust Fund could provide a financial guarantee or modest credit line to the WFP, which would enable it to enter into commodity derivative contracts up to one year in the future. With appropriate policies in place, the practical Trust Fund impact would be very modest.

(4) Utilize Forward Purchase(s) for In-Kind Contributions: Currently, U.S. in-kind contributions are appropriated based on monetary values instead of metric tonnage. This shifts commodity price risks to the WFP and food beneficiaries. The US could procure part of its in-kind contributions to the WFP through forward purchases. As this would provide increased price certainty for American farmers; it may be politically palatable to Congress. Other countries which make in-kind purchases might also consider this approach. 


\section{OVERVIEW}

The World Food Programme (WFP) is the largest multilateral humanitarian agency providing food to the chronically undernourished. Established in 1963, it has provided food assistance to nearly 1.4 billion people since inception. ${ }^{1}$ The WFP's most visible presence is in emergency operations, providing food assistance during conflicts or following natural disasters. It also provides assistance on a more protracted basis. Its work has become an even more critical stopgap instrument in an era of high food prices and resulting higher numbers of hungry people around the world. In 2008, the WFP delivered food assistance to 102 million people in 78 countries based on donor contributions of almost $\$ 5$ billion.

\section{$\underline{\text { Trends in Food Prices }}$}

In 2008, developing countries experienced an acute food shock brought on by a dramatic increase in global fuel, transport, and food prices. But this was part of a larger trend-food prices began to increase in 2004 and between 2006 and 2008, the average world prices for maize, wheat, and rice more than doubled. The ultimate result was acute food shortages, civil unrest, and a dramatic rise in the number of food vulnerable people.

The food price crisis of 2008 illustrates the volatility of commodity prices, and the danger this poses to efforts to alleviate poverty. Rising food prices disproportionately affect the world's poorest citizens - the World Bank estimated that as many as 100 million additional people were severely affected by the high price of food in 2008 (World Bank, 2008). A significant share of this group lives in Africa, in countries which were already struggling to address problems of chronic malnutrition, hunger and infant mortality. Figure 1 shows the price of wheat, soybeans and rice as well as an overall index of food commodities over the last decade.

\footnotetext{
${ }^{1}$ WFP FAQ's, www.wfp.org
} 
Figure 1 - Food Crop Prices, 1998-2008

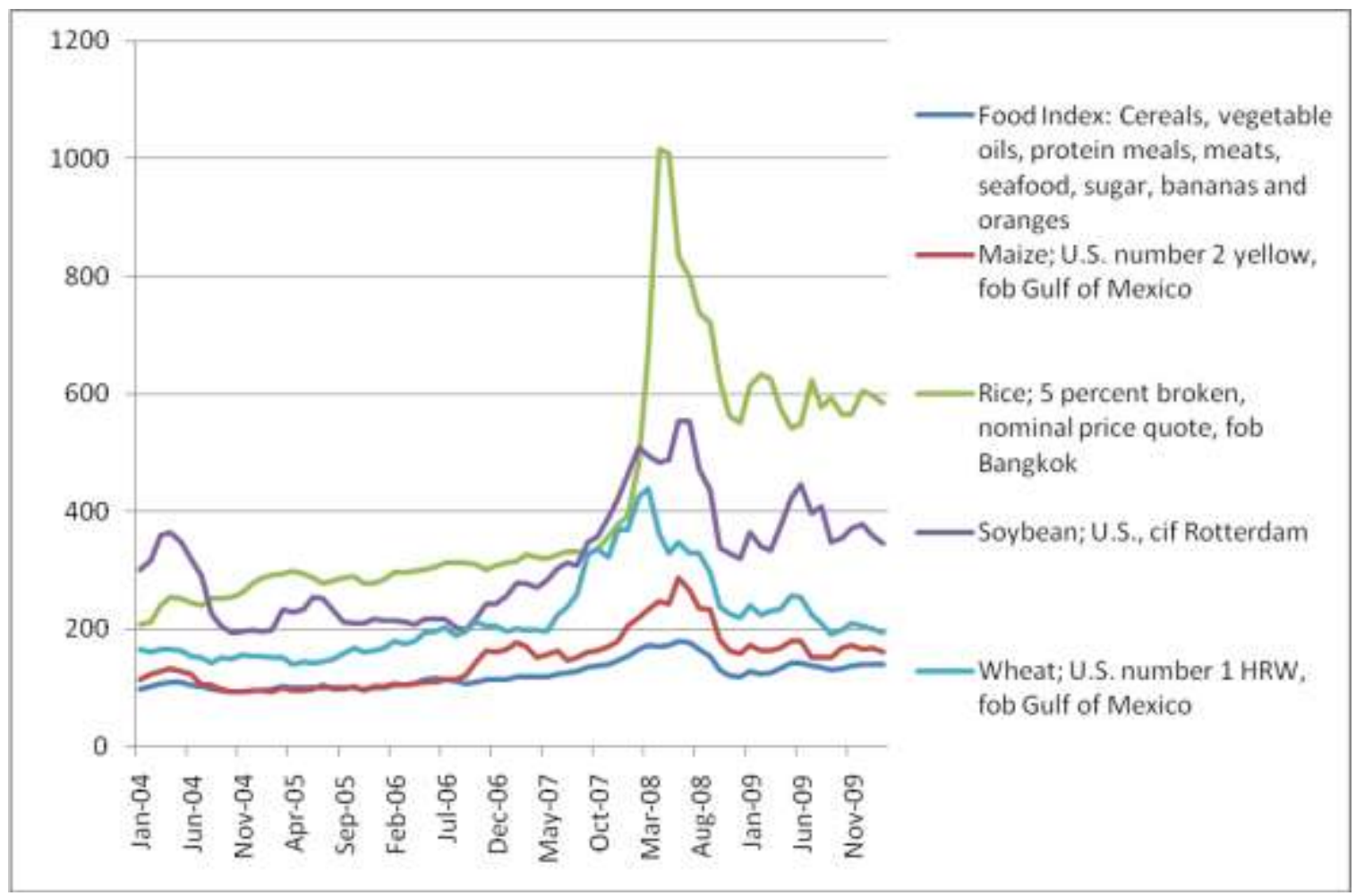

Source: IMF Primary Commodity Prices www.imf.org

In a recent paper, Nora Lustig argues that periods of rising food prices cause policy dilemmas for developing country governments. Letting domestic prices adjust to reflect the full change in international prices generates inflationary pressures and causes severe hardship for poor households lacking access to social safety nets (Lustig, 2009). She writes that governments can use food subsidies or export restrictions to stabilize domestic prices, but this exacerbates global food price increases and undermines a rules-based trading system. In 2008, many countries chose to shift the burden of adjustment back to international markets. The use of corn and oilseed for the production of biofuels has only made the problem worse (Elliott, 2008). In addition, rising standards of living in India and China, the rapid depreciation of the US dollar against the Euro and other currencies and speculation in commodities markets have all contributed to rising food prices (Timmer, 2008). Figure 2 shows the countries that continue to be most at risk from high food prices. 
Figure 2 - Countries Most At Risk from High Food Prices

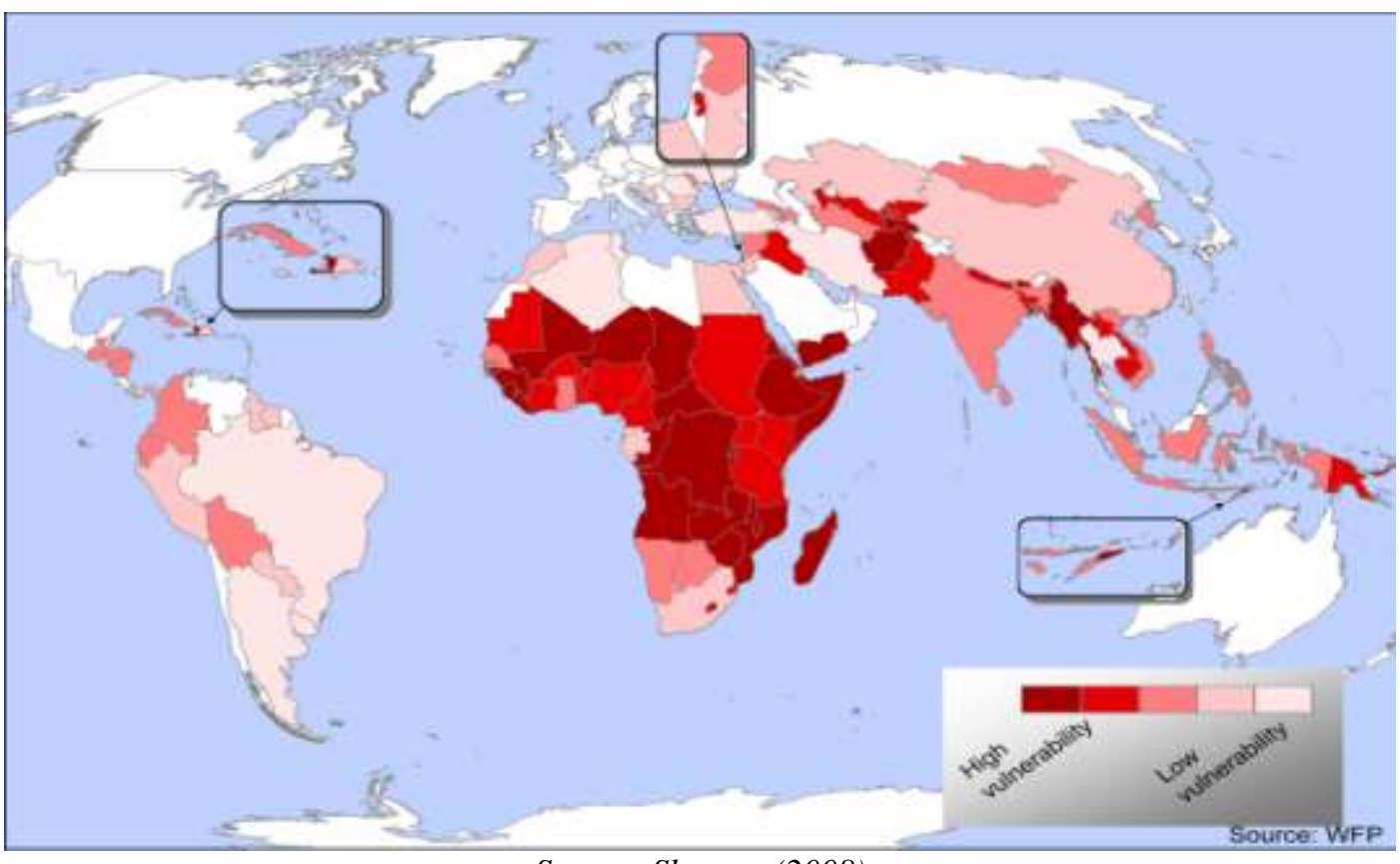

Source: Sheeran (2008)

While the issue of long-term assistance and strategic direction is beyond the scope of this paper, it is worth noting that the food supply response to the current crisis will likely take significant time (a decade at the very least) to produce material results, as was the case in 1973-74. This presents an enormous challenge - there is little unused productive land left and the yieldpotential of current technologies has been static for decades. Invariably, new crop technologies will underpin an expansion of global food supplies. Governments and the international community must make robust investments in the development of new seed varieties, extension systems, and key inputs such as fertilizer, in order to boost the production of food. Countries in Sub-Saharan Africa and elsewhere also must have better access to world markets to purchase food as well as seeds, fertilizer, and other key inputs, at prices that are not distorted by protectionist policies or hoarding. Institutions - at the international, regional, national and local level - that are focused on the development of new technologies that will increase crop yields or improve resistance to drought and disease should be provided with the resources they need.

This paper focuses solely on some of the key issues that the WFP and its donors must face in the immediate- to medium-term. Due to the factors mentioned above, food security will remain a pressing international issue in the years to come. In this context, the WFP will continue to play a critical frontline role and must be properly equipped to do its job. Given the importance of WFP's role, and the possibility of future crises, appropriate and effective management of price risk is an essential component of its business model. We outline options for the WFP and its Board to finance operations, based on a total projected work program of about $\$ 5-\$ 6$ billion per year (WFP, 2010). 


\section{$\underline{\text { WFP Operations }}$}

WFP operations comprise three main types of programs, all initiated by a country office and each set for predetermined amounts of time and specific purposes.

(1) Emergency Operations - These operations are intended to address the effects of natural disasters, droughts, crop failures, and conflict. In the event of a crisis, respective WFP Country Directors can draw up to $\$ 500,000$ from the Immediate Response Account, to be used for up to three months. After this initial period, the Country Director designs an Emergency Operation (EMOP) - against which the WFP issues specific donor appeals. EMOPs may last up to 24 months, after which a Protracted Relief and Recovery Operation is initiated as needed.

(2) Protracted Relief and Recovery Operation - After Emergency Operations expire, PRROs can be initiated to address longer-term food security needs. They have specific components designed to free recipients from food-security needs so they can focus on education or rebuilding infrastructure. WFP also takes the lead in providing food in refugee or Internally Displaced Persons (IDPs) camps. PRROs cannot last more than three years.

(3) Development Operations - A small component of WFP operations are focused on longerterm development issues. Over the past 9 years, these types of operations have constituted less than 9 percent of total WFP program spending.

Table 1 shows the top WFP assistance recipients by year. Appendix I provides a detailed listing of recipient countries.

Table 1 - Top WFP Assistance Recipients by Year

\begin{tabular}{|llll|}
\hline Year & \multicolumn{1}{c}{ Emergency Ops } & $\begin{array}{c}\text { Protracted Relief } \\
\text { and Recovery }\end{array}$ & Development Ops \\
\hline 2001 & Korea Dem Rep & Angola & Ethiopia \\
2002 & East and Central Africa & Angola & Nepal \\
2003 & Iraq & Angola & Ethiopia \\
2004 & Sudan & Afghanistan & Bangladesh \\
2005 & Sudan & Ethiopia & Bangladesh \\
2006 & Sudan & Afghanistan & Bangladesh \\
2007 & Sudan & Uganda & Bangladesh \\
2008 & Sudan & Ethiopia & Bangladesh \\
2009 & Sudan & Ethiopia & Ethiopia \\
\hline
\end{tabular}

Source: World Food Programme

Figure 4 illustrates the number of people assisted by the WFP, and the amount of food distributed for each year from 2001 to 2008. The number of people rose substantially in 2003 and 2004, in part because of WFP activities in Iraq. However, after that, the WFP's marginal ability to feed hungry people declined (even as food prices began to rise). The number of people receiving WFP food assistance declined by over 20 million - falling below 90 million in 2007 . In 2008 - the year in which food prices rose sharply - the WFP was able to raise additional 
emergency appeal funding to provide food assistance to 102 million people in 78 countries, many of which were in Sub-Saharan Africa. Given the sharp increase in chronic hunger in 2008, one can argue that this response fell well short of demonstrable needs.

Figure 4: WFP Operations, 2001-2008

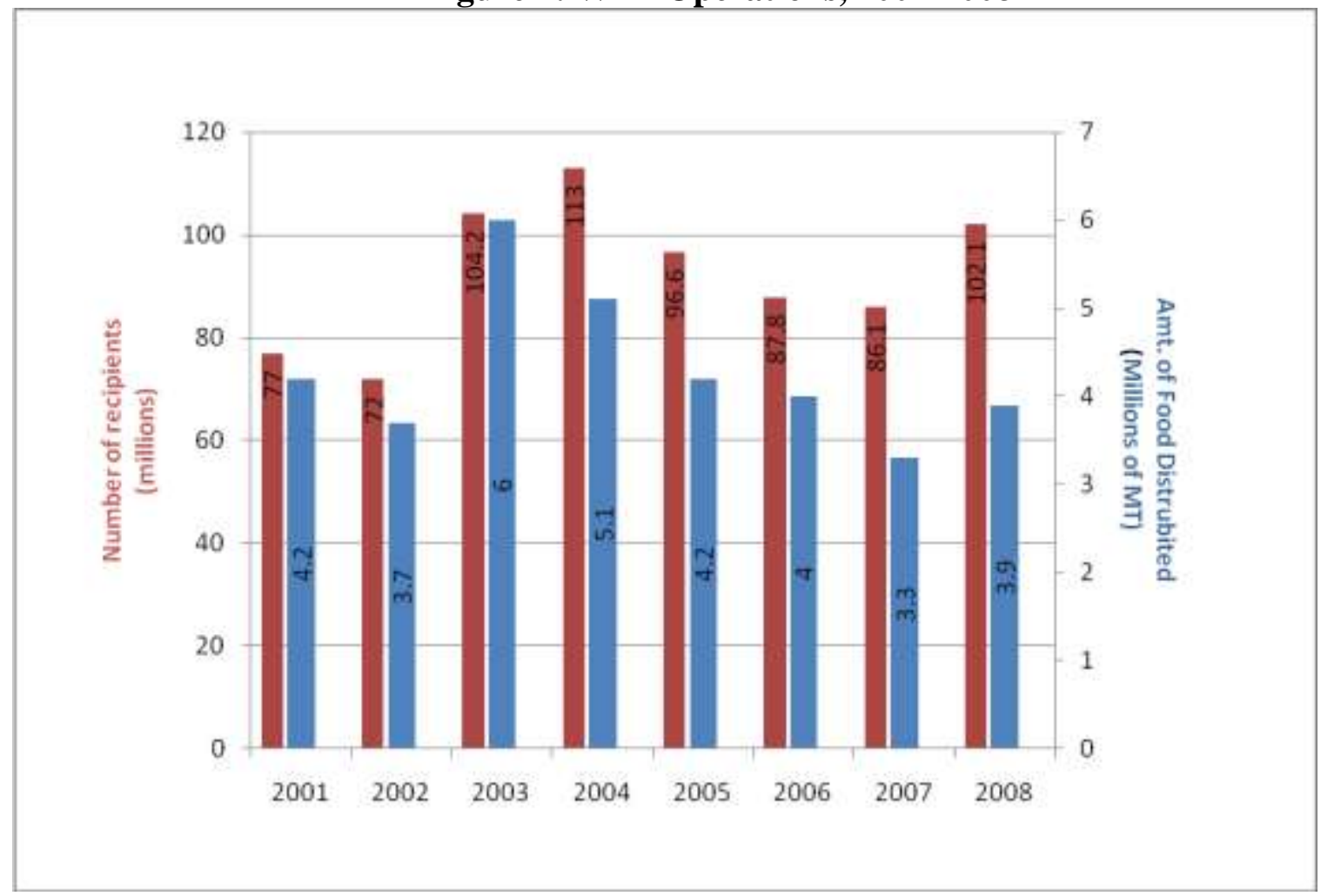

Source: WFP annual reports and author calculations

Despite price fluctuations, a significant portion of the WFP's activities are more predictable than one might imagine. Most policymakers believe that food aid is a highly volatile and unpredictable business. Natural and man-made disasters (earthquakes, tsunamis, war) do create unforeseen food emergencies throughout the world every year. However, our examination of WFP country operations over the last decade finds a material amount of predictability in several chronically vulnerable countries. Figure 3 above demonstrates that a small number of countries are often the top recipients of WFP food assistance operations year after year. Furthermore, Table 2 shows that ten countries accounted for over half of WFP food operations, on average, between 2001 and 2009 (see appendix I for details). While these countries also experienced year-to-year fluctuations, the WFP maintained sizable food assistance operations every year and is projected to continue doing so over the near- and medium-term. 
Table 2 - WFP Operations in Select Countries, 2001-2009

\begin{tabular}{|c|c|c|c|c|c|c|c|c|c|}
\hline RECIPIENT (USD Millions) & 2001 & 2002 & 2003 & 2004 & 2005 & 2006 & 2007 & 2008 & 2009 \\
\hline Afghanistan & 143.8 & 230.1 & 76.3 & 93.6 & 74.3 & 126.8 & 85.4 & 358.0 & $\overline{91.0}$ \\
\hline Burundi & 29.6 & 24.0 & 19.7 & 15.8 & 16.3 & 23.8 & 41.9 & 43.6 & 20.4 \\
\hline Congo Dem Rep & 36.5 & 28.1 & 63.0 & 30.9 & 49.6 & 60.2 & 105.0 & 145.3 & 125.3 \\
\hline Ethiopia & 83.4 & 175.3 & 225.2 & 169.4 & 365.9 & 138.1 & 127.6 & 462.4 & 335.8 \\
\hline Kenya & 107.2 & 31.4 & 31.5 & 78.6 & 64.4 & 230.6 & 118.3 & 189.9 & 208.3 \\
\hline Somalia & 3.0 & 7.2 & 8.5 & 22.0 & 19.6 & 65.0 & 86.9 & 227.6 & 145.3 \\
\hline Sudan & 120.8 & 128.3 & 116.2 & 561.2 & 360.6 & 708.2 & 542.6 & 710.1 & 385.0 \\
\hline Tanzania & 46.1 & 16.7 & 56.9 & 21.3 & 24.7 & 29.2 & 33.7 & 20.2 & 19.8 \\
\hline Uganda & 10.7 & 9.9 & 92.0 & 83.5 & 98.3 & 97.1 & 134.7 & 92.6 & 55.3 \\
\hline Zimbabwe & 0.0 & 73.8 & 66.9 & 31.9 & 28.1 & 46.4 & 128.6 & 208.9 & 91.0 \\
\hline Total & 581 & 725 & 756 & 1,108 & 1,102 & 1,525 & 1,405 & 2,459 & 1,477 \\
\hline (\% of WFP Total) & $37 \%$ & $52 \%$ & $36 \%$ & $59 \%$ & $51 \%$ & $70 \%$ & $63 \%$ & $64 \%$ & $59 \%$ \\
\hline
\end{tabular}

Source: World Food Programme

\section{Procurement Using Cash}

WFP food purchases - as opposed to in-kind donations from donor governments - accounted for a modest proportion of total food assistance before $1974 .^{2}$ More recently, food procurement as a method of delivering food assistance has been increasing steadily (see figure 6 below).

\section{Figure 6 - WFP Procurement Using Cash}

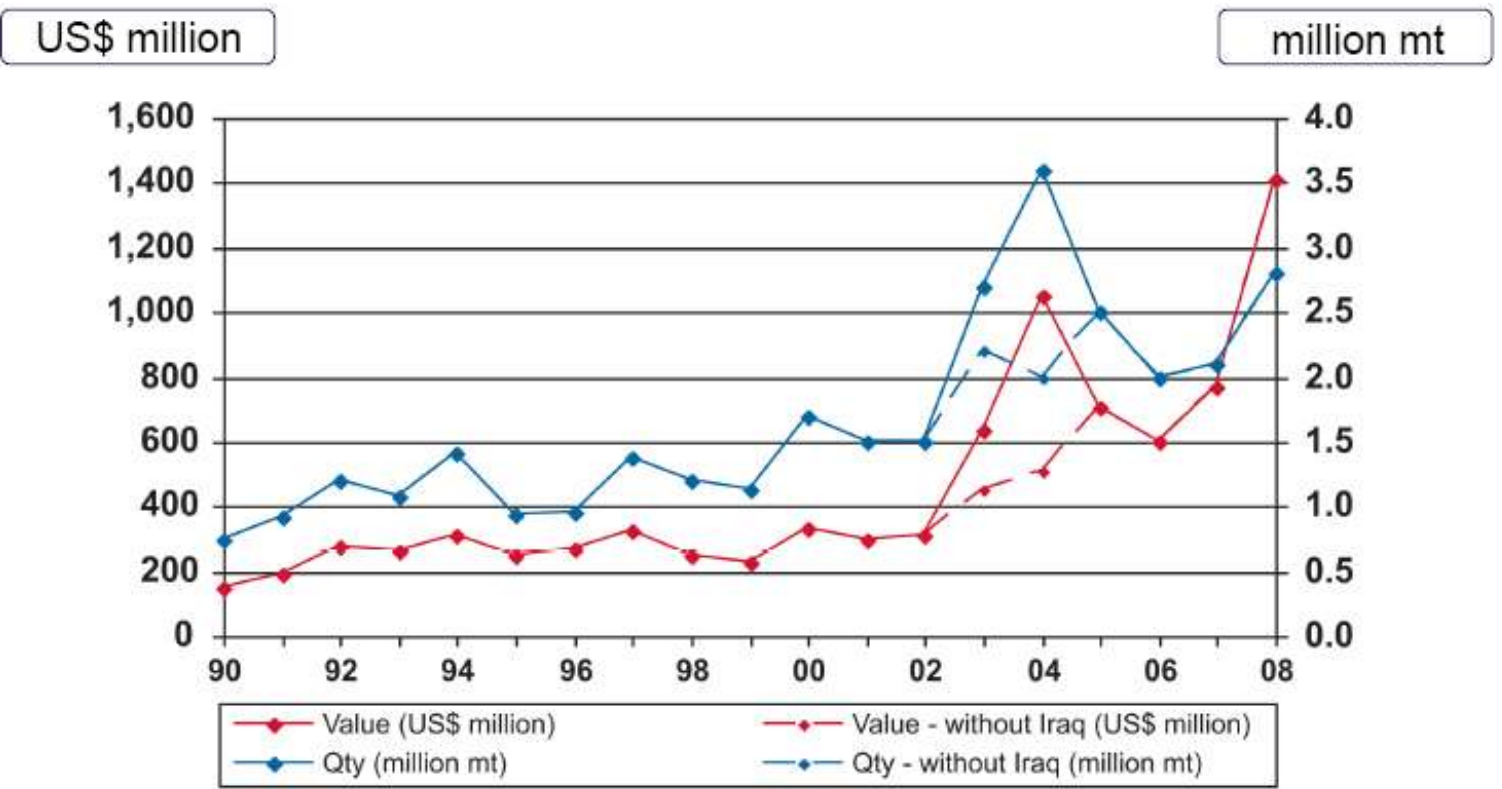

2003 includes $518,000 \mathrm{mt}$ worth US\$ 182 million for Iraq

2004 includes 1,562,000 $\mathrm{mt}$ worth US\$ 540 million for Iraq

Source: World Food Programme

\footnotetext{
${ }^{2}$ At the World Food Conference in 1974, donors were urged to provide cash in order to facilitate commodity purchases in developing countries. More recently, Ed Clay has called for more attention to be given to the WFP mandate (Clay, 2003).
} 
In 2008, the WFP purchased 1.9 million metric tons of food - valued at about $\$ 1.4$ billion. These purchases represent around 56 percent of total operations expenditures for that year - of which, over three-quarters were sourced in developing countries. In fact, the WFP has mandated the preference for local or regional purchases when funding is unrestricted. ${ }^{3}$ This highlights that the WFP is not hamstrung by restrictive internal policies, but rather by donors' unwillingness to provide unrestricted cash contributions. In 2008, developing countries accounted for 4 of the top 5 countries for sourcing purchased food (see Table 3 below). ${ }^{4}$

\section{Table 3 - WFP 2008 Commodity Purchases by Top 15 Countries of Origin 5}

\begin{tabular}{lccc}
\multicolumn{1}{c}{ Country } & Value (US\$ millions) & \% of Total & Local Destination (\%) \\
\hline South Africa & 164 & 11.63 & $0 \%$ \\
Ecuador & 100 & 7.10 & $99 \%$ \\
India & 98 & 6.98 & $18 \%$ \\
Canada & 89 & 6.34 & $0 \%$ \\
Peru & 63 & 4.46 & $99 \%$ \\
Turkey & 54 & 3.87 & $0 \%$ \\
Uganda & 53 & 3.77 & $58 \%$ \\
Malaysia & 45 & 3.17 & $0 \%$ \\
Belgium & 44 & 3.14 & $0 \%$ \\
Sudan & 43 & 3.04 & $95 \%$ \\
France & 42 & 2.97 & $0 \%$ \\
Indonesia & 37 & 2.62 & $26 \%$ \\
Italy & 35 & 2.50 & $0 \%$ \\
Bulgaria & 33 & 2.34 & $0 \%$ \\
Ethiopia & 30 & 2.15 & $24 \%$ \\
TOTAL & 930 & 66.08 & - \\
\multicolumn{1}{c}{ Source $:$ WFP Food Procurement: World View 2008 (online database) }
\end{tabular}

\section{IMPACT OF PRice Volatility ON WFP OPERATIONS}

In response to the 2008 food shock, the WFP issued an extraordinary emergency appeal to address the increased number of food vulnerable people and offset significantly higher food delivery costs. Forced to purchase food commodities at spot market prices, the WFP was completely exposed to continuously increasing price levels, which resulted in a budget gap of 40 to 50 percent by some accounts. The net impact was dramatically higher per capita food assistance delivery costs. In 2007, the WFP was able to provide 3.3 million metric tons of food

\footnotetext{
${ }^{3}$ The WFP believes that local or regional purchases reduce transport costs and delivery times as well as support market incentives for food production.

${ }^{4}$ There is of course, a debate on the impact of local procurement on prices and livelihoods (Aker, 2008). Some argue that local procurement actually drives prices up at the worst possible time for poor consumers. But this is in large part due to the fact that purchases are in spot markets, and often occur when prices are already at their peak. Longer term purchases in futures markets are less likely to have this kind of negative impact. See Appendix III for more detail on Aker's analysis of local procurement and the newly-announced Purchase for Progress initiative.

${ }^{5}$ Local destination percentage figures are based on author calculations utilizing average costs per commodity (locally-sourced metric tonnage / total sourced metrics tonnage * total cost) and then aggregating the respective commodity groups.
} 
to 88 million people following contributions of $\$ 2.7$ billion. In 2008 , as the number of hungry people rose dramatically, the WFP provided only an additional 600,000 metric tons of food to 16 million extra people, based on donor contributions of over $\$ 5$ billion. ${ }^{6}$ Put differently, donor contributions increased by 86 percent in 2008, but only delivered 18 percent more food by volume to 19 percent more people. This is in part due to WFP's own internal constraints but is also driven by the fact that higher spot prices had a direct impact on the WFP's budget. Recent research suggests that spot prices are more variable on the SAFEX commodity exchange in South Africa than at the Chicago Board of Trade (Geyser and Cutts, 2007).

Could the WFP have done better if it had purchased preemptively? One prerequisite for advance purchasing is greater financial certainty - this would likely have enabled WFP to use its advance purchase facility during the food crisis of 2007-08. Since 2005, the WFP has an advance financing facility of $\$ 180$ million that serves as a revolving fund for purchases of commodities, including some advance purchases in spot markets which have reduced delivery times (WFP, 2005). This facility has reduced delays in delivery times and led to more efficient operations in some countries. A significant increase of resources to this facility to cope with rising demand (which manifested as early as 2007) would likely have been helpful to meeting demand in a timely manner in 2008.

Can the WFP go further - to use futures markets? To illustrate this, we examine the price differential between spot and futures markets for maize, which constitutes a significant part of WFP procurement in many recipient countries. ${ }^{7}$ In some cases, multiple, separate procurements were executed on the same date, so we have aggregated these transactions into the total quantity purchased by WFP for each respective day and matched them to price data from SAFEX on 3, 6 and 9 months futures. Note that these transactions do not represent the entirety of maize purchases for Africa during this period, but rather those for which we are able to match WFP procurement times and quantities with available futures contract dates from SAFEX. Nor do they reflect the prices that WFP actually paid, but rather a simple comparison of spot and futures prices in SAFEX, using WFP quantities and dates of transaction. As such, it is a hypothetical example. WFP's procurement process is more complex, and necessarily involves other logistics costs that cannot be easily compared in this exercise.

Figures 9 and 10 show the difference between spot and futures prices for yellow maize for Africa, over an extended time horizon for which we have data from SAFEX (2001 to 2009). ${ }^{8}$ For the calculation in figure 10a, we use futures contracts from 90, 180, and 270 days before the date of actual procurement. Using 1423 data points for 3 month contracts, 1099 for 6, and 780 for 9, we calculate the price differential to futures contracting. Over the whole series, there are positive and substantial savings for 3,6, and 9 month hedging strategies, though these should not necessarily be taken as an indicator of future performance. Figure 10 shows the average spot and futures prices for matched dates in the 10 year sample of maize sent to Africa. Of course, this is

\footnotetext{
${ }^{6}$ Source: WFP 2009 Annual Report.

${ }^{7}$ Maize accounted for 22 percent of WFP procurements in 2008. Source: WFP Procurement Database.

${ }^{8}$ Data is derived from the South African Futures Exchange (SAFEX) online database for futures and spot market prices. We recognize that WFP purchases both white and yellow maize for Africa but use yellow maize here as an illustrative example. Figure 10 demonstrates hypothetical gains and losses from engaging in futures markets, but does not include transactions costs that might be incurred.
} 
only one example and there are periods when spot prices are indeed lower than futures prices in commodity markets. The lesson is not that there are always monetary gains to be made from hedging but that it is a means by which the certainty of food availability might be increased. Indeed, the whole point of hedging is to transfer price risks up and down to other parties, to better manage financial flows.

There are non-monetary gains from hedging as well (Slater and Dana, 2006). These include signals to the public and private sector about the quantity and price of purchases by the government, which in turn better defines the parameters in which the commercial sector operates. Slater and Dana argue that Malawi's use of a physical call option in 2005-06 resulted in a defined space for commercial imports where government and donors operated only as a contingent last resort. Interestingly, the maize bought under the call option had the best delivery performance of all purchases, thereby reducing disruptions in the food pipeline.

What are the options for the WFP? First, execution of a prudent financial risk management strategy requires a commitment to pursue hedging operations over an extended time horizon. In this context, the WFP will achieve costs savings in some years and relative losses in others. But overall, the goal is to achieve two important objectives: (1) average cost savings over time; and (2) more predictable operational cost projections which enhances budget preparation and execution. With respect to (2), this would obviate the need for the WFP to seek extraordinary supplemental donor contributions to offset increased costs resulting from commodity price increases. In this vein, the WFP would lock in a prudent percentage of its planned operations early in the year.

Second, there are ways that the WFP can minimize the prevalence of relative price losses resulting from hedging operations. In this context, we recommend that the WFP actively incorporate annual commodity price forecasts into its financial planning processes. Most investment banks produce commodity analyses and price projections on a regular basis. In addition, the World Bank regularly circulates its so-called "Pink Sheets," which provide price forecasts for 45 commodities over the near-, medium-, and long-term. ${ }^{9}$ However, World Bank price forecasts do not cover specific months - only annual figures. Therefore, we suggest that WFP staff work closely with the respective World Bank staff on a regular basis to incorporate the latest available information into their financial planning processes. For example, the WFP may wish to apply hedging transactions to a smaller share of its projected operations (or none at all) when commodity prices are projected to decline over the respective time period. Alternatively, it may wish to utilize options contracts when consensus forecasts suggests a decline in respective commodity prices (section III examines these issues in greater detail). In this manner, commodity price forecasts would provide an additional filter into the WFP's broader hedging strategy and decision making process.

Overall, we believe that the WFP will be able to provide assistance to more people and stretch its funding further if it devises a sound financial management strategy to procure food in futures or options markets over a medium- to long-term time horizon. In the next section, we will discuss alternative approaches that may be appropriate for the WFP.

\footnotetext{
${ }^{9}$ These Pink Sheets cover several WFP-relevant commodity groups (maize, wheat, rice, and sugar), which accounted for over 60 percent of WFP procurements in 2008. Source: WFP Procurement Database, 2008.
} 
Figure 9 - Differences in Futures vs. Spot Prices of Yellow Maize, 2001-2009 (USD millions)

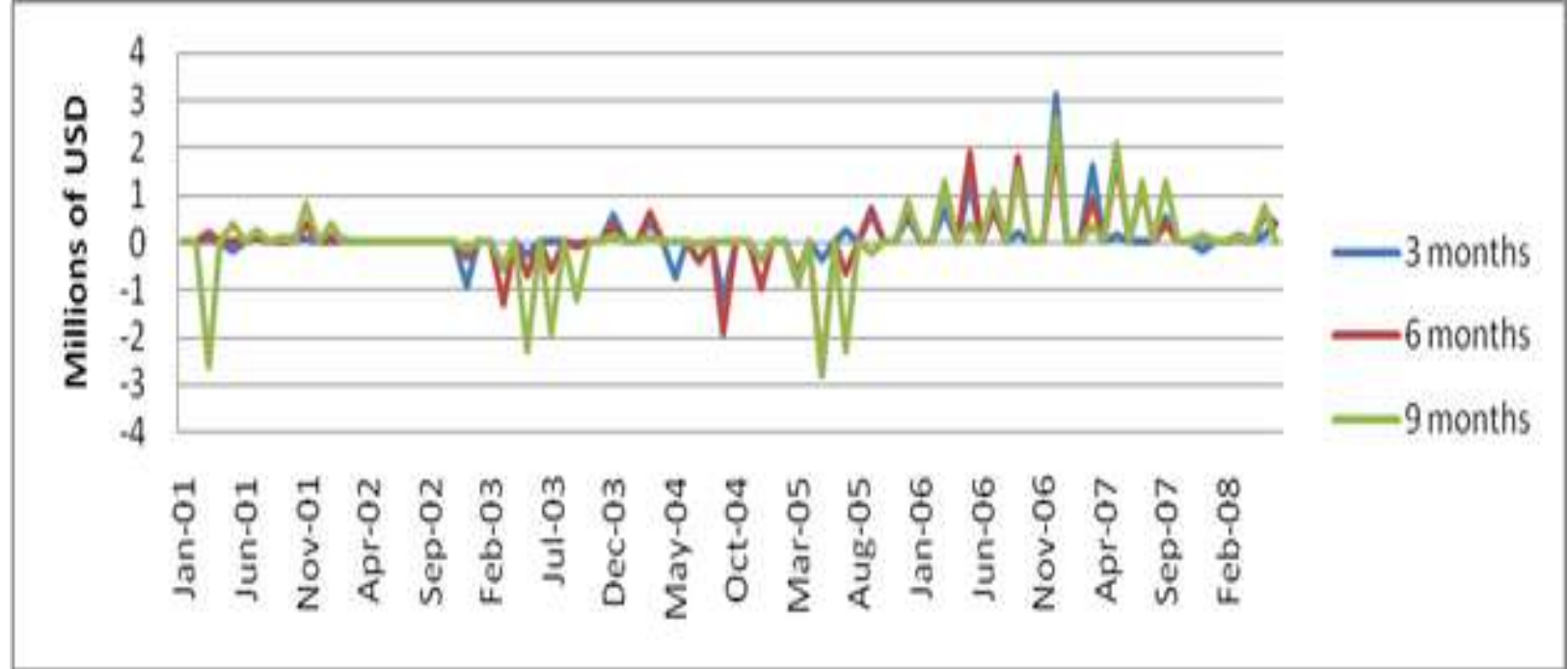

Source: SAFEX; gains are positive when futures prices are lower than spot prices.

Figure 10 - Average Prices for Yellow Maize Procured for Africa, 2001-2009

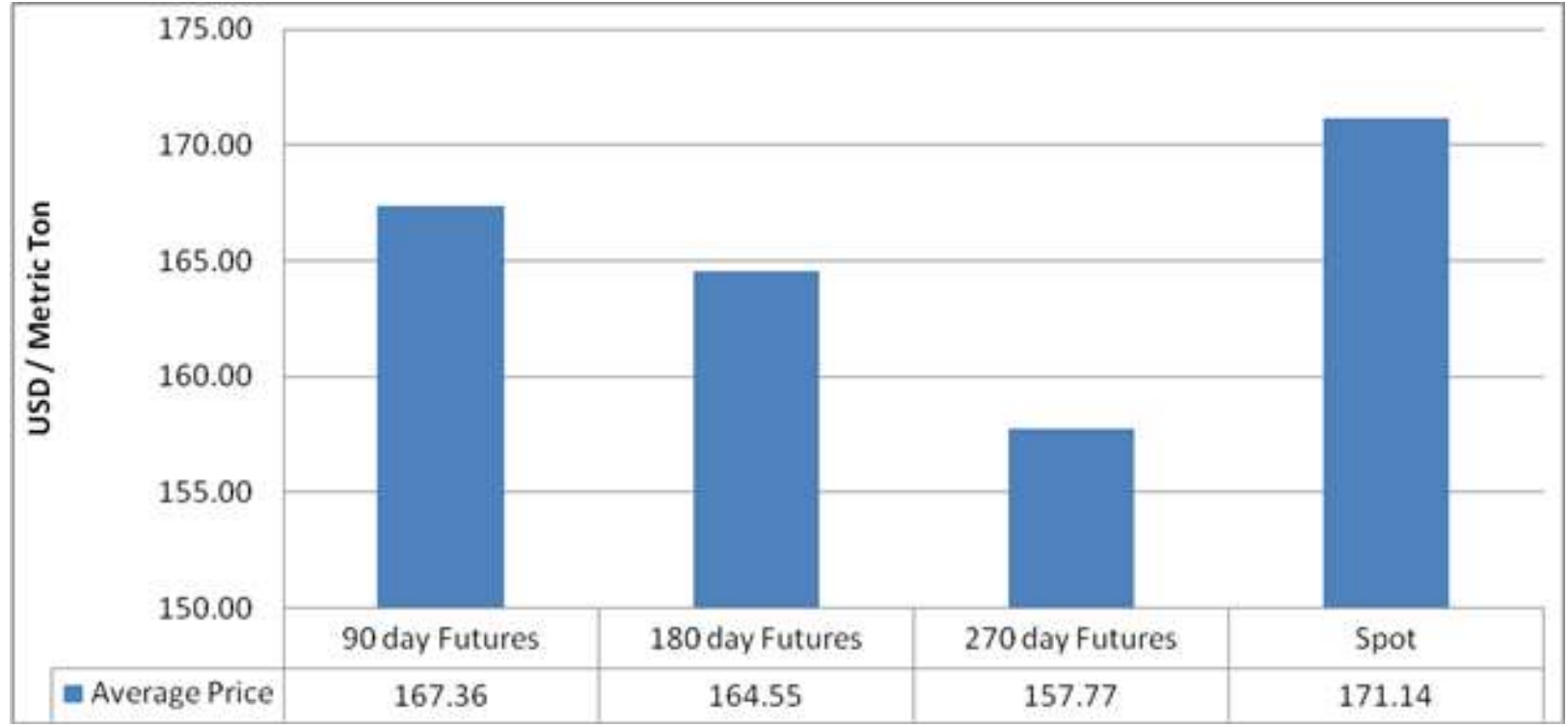

Source: SAFEX

\section{WFP FinANCIAL MANAGEMENT OPTIONS}

The WFP is largely unable to plan or execute preemptive purchasing beyond immediate-term time horizons. Specific procurement events only occur in response to requests from a respective country office. Once the request is made, the Food Procurement Service in the Operations Department (not the country office) determines the best procurement strategy based upon need, 
urgency, location, and cost considerations. In all purchase decisions, the WFP tries to avoid purchasing above import parity (i.e. the cost of importing the same commodity locally from the international market). Another important factor is that the WFP waits for confirmed cash resources before contracting commodities, which has led to further delays in operational deployments. $^{10}$

\section{Increasing Efficiency of Food Purchases}

An improvement in the predictability of finances can at the very least, lead to increased efficiency in spot market purchases. As mentioned earlier, the WFP has made good use of donor commitments made to set up an advance purchase facility. In 2008, it obtained 238,000 metric tons of cereals for 9 operations in Africa using this facility, reducing delivery time from 3 months to 1 month (Milken Institute, 2009). An increase of resources to this facility may well lead to efficiency gains, and might be a good first step towards closing the gap between projected needs and financing levels.

However, the WFP has not executed any hedging operations to manage price risk exposure. While the WFP Board has expressed an interest in examining these issues, ${ }^{11}$ no concrete action has been taken to date. As such, all WFP food purchases are executed at spot market prices. As a result, increases in food and transport price levels - such as the dramatic rise in 2008 - create an enormous financial burden on the WFP and its ability to feed people who are most vulnerable to these same food price shocks.

A prudently executed hedging would have provided significant risk management and mitigation during the 2008 food crisis. In this section, we outline some WFP financial management options for operationalizing a hedging strategy. This analysis is carried out solely for illustrative purposes and the WFP ultimately would need to develop a comprehensive financial management strategy to implement the hedging options discussed here. ${ }^{12}$

\section{Targeted Hedging Methodology}

The WFP should consider implementing a hedging initiative specifically targeting several of the most chronically vulnerable countries on a pilot basis. In this context, we recommend a highlyconservative, multi-step methodology to determine the portion of WFP's projected operations appropriate for financial risk management. The approach's conservative controls help to mitigate any potential fluctuations involved with projecting food assistance delivery requirements up to one-year in advance.

\footnotetext{
10 "Food Procurement in Developing Countries", WFP 2006

${ }^{11}$ Source: WFP (2006), "Food Procurement in Developing Countries".

${ }^{12}$ A broad range of options was recently outlined in a report from the Milken Institute which brought together experts in the area of food aid, commodity trading and risk insurance. The report, entitled "Feeding the World's Hungry," is available at www.milkeninstitute.org
} 
(1) Historical Baseline: As a first step, the WFP could utilize historical food deliveries as an indication of future operational plans. In this manner, it could target a conservative amount of past deliveries for future hedging - such as the historical minimum or median level. An even more conservative approach would be to target a set percentage of these historical levels, such as 75 percent, for targeted hedging operations.

(2) Projected Needs Filter: The second step would incorporate the WFP's annual country-bycountry program projections for food assistance deliveries. In this context, the WFP's country program strategies, early famine warning system, and other resources would play important roles. This would provide a forward-looking, demand-based check on projected hedging needs and permit necessary upward or downward adjustments as appropriate.

(3) Commodity Filter: The next step is to determine the associated commodity mix of projected WFP country operations. ${ }^{13}$ Derivative instruments are not widely available for several core WFP commodity groups - such as pulses and maize meal - and therefore would need to be excluded from any hedging strategy calculations. Nonetheless, commodity groups accounting for over 60 percent of total WFP market purchases last year could be covered by hedging instruments available on different commodity exchanges. ${ }^{14}$

(4) Regional Clustering: As a fourth step, the WFP could consider pooling relevant hedging projections on a regional basis. This could help to further address any unforeseen countryspecific fluctuations. For example, East African countries (Ethiopia, Kenya, Somalia, and Sudan) could be bundled together. Country clustering would address regional similarities in hunger seasons, drought conditions, and other common factors. This may not be appropriate for physical delivery futures contracts ${ }^{15}$, but could be relevant for stand-alone futures, forwards, or options contracts (see additional information on this below).

(5) Operational Timing: Fifth, the WFP would utilize historical data and its decades of country expertise to determine seasonal or monthly need projections. For example, Zimbabwe's hunger season typically begins in November/December and ends with maize harvests in the March/April period. Again, the WFP may want to enter into hedging contracts corresponding to a conservative percentage of these month-by-month operational need projections.

(6) Projected Unrestricted Donor Contributions: As a sixth step, the WFP would compare the relevant aggregated hedging and timing components against projected unrestricted donor

\footnotetext{
${ }^{13}$ In 2008, the breakdown of WFP commodity group procurement was: (1) wheat -22 percent; (2) maize - 22 percent; (3) rice - 16 percent; (4) blended food - 12 percent; (5) pulses -8 percent; (6) sorghum -4 percent; (7) wheat flour -4 percent; (8) maize meal -4 percent; (9) vegetable oil -4 percent; (10) sugar -2 percent; and (11) other -2 percent. Source: WFP, 2008 Food Procurement Annual Report.

${ }^{14}$ Wheat, maize, rice, and wheat flour accounted for 63 percent of WFP market purchases in 2008. Source: WFP, 2008 Food Procurement Annual Report.

${ }^{15}$ These contracts stipulate the purchase of a specific commodity volume (ex - 100 metric tons of white maize) and physical delivery to a specific location at a future date. The inclusion of specific delivery locations could prevent regional clustering unless the WFP utilized a regional warehouse supply chain system for delivery to neighboring countries.
} 
contributions ${ }^{16}$ and relevant restricted cash contributions ${ }^{17}$ for the coming operational year. Similar to other steps, the WFP may wish to limit hedging operations to a conservative portion of these relevant, cash-based contribution resources. This would ensure that the WFP does not enter into hedging contracts exceeding resources available for the targeted countries.

(7) Commodity Price Projections: As noted in section II, the WFP would consult consensus views (investment bank and World Bank reports) to determine whether specific commodity prices are projected to increase or decrease over the respective time period. If prices are projected to decline, then the WFP may wish to execute procurements at spot market prices. Alternatively, it may wish to execute options contracts (see details below) to provide maximum flexibility and account for any unforeseen changes in the market price environment.

(8) Currency Risk Exposure: As WFP operations are denominated in United States dollars, attention must be paid to potential currency risk associated with hedging contracts denominated in another foreign currency (ex - South African Rand). This is an additional component that should be managed through currency-related derivatives, such as currency futures or swaps. Currently, the WFP does limited currency hedging (dollar vs. euro) but this is not in connection with commodity purchases.

\section{$\underline{\text { Selection of Appropriate Hedging Instruments }}$}

There are several risk management instruments available for WFP operations, such as futures, forward, and options contracts. All instruments are utilized widely as a secure, inexpensive, and flexible way to manage risk. Once the WFP determines the respective operations appropriate for hedging (per the aforementioned illustrative methodology), it will need to select the hedging instruments most appropriate to meet its needs. As noted below, there are pros and cons associated with each instrument. For example, if the WFP prioritizes flexibility, then it may wish to utilize options contracts instead of forward contracts. Alternatively, if firm financial planning is the most important objective, then it may prefer forward contracts. Again, we recommend that it enlist the assistance of a financial advisory firm to establish and execute the most appropriate and prudent risk management strategy.

- Options Contract: This is perhaps the most straightforward of all the options available to the WFP and is likely the place to start in terms of using hedging instruments. An options contract offers the buyer the right - but not the obligation - to purchase a commodity at an agreed-upon price during a specified period of time or on a specific date. Similar to futures contracts, options include a set purchase fee that may be set up front in the origination market or according to market prices in a secondary market. A physical call option ensures that the commodity is actually delivered to the agreed-upon destination. In 2005, the Government of Malawi, with the assistance of the World Bank, made use of a physical call option to

\footnotetext{
${ }^{16}$ As noted in the previous section, unrestricted donor contributions have averaged roughly 13 percent of total WFP contributions over the last ten years.

${ }^{17}$ The relevant tied donor contributions would relate to those countries targeted for hedging operations.
} 
purchase maize for the lean season, which resulted in savings of $\$ 50-\$ 90$ per ton for the government (Milken Institute, 2009).

- Futures Contract: A futures contract is an agreement typically executed on an exchange trading floor entailing the purchase/sale of a commodity or financial instrument at a predetermined price at a set future date. Futures contracts have standardized quality and quantity requirements to facilitate efficient trading. Some futures contracts may call for physical delivery of the asset, while others are settled in cash. Futures exchanges guarantee transaction performance by the relevant counterparties. In return, they charge an 'insurance' transaction fee usually between 0.25 and 1 percent of the underlying contract value.

Moreover, futures contracts are tradable, which permits offloading positions before delivery without requiring the original counterparty's permission. ${ }^{18}$

- Forward Contract: A forward contract (or simply a "forward") is an agreement between two parties to buy/sell an asset at a future date for an agreed price. Payment for the underlying asset is provided before control of the instrument is transferred. Unlike futures contracts, there are no upfront transactions costs (exchange market fees, etc). However, counterparties may require collateral as a guarantee. Also, forward contracts typically do not have uniform standards (ex - quality or quantity), which would require due diligence of the counterparty's track record of consistently delivering quality product on time. Also, forward contracts are not traded on exchanges, which make offloading them a difficult, intensive, and unattractive option. The WFP will also need to guard against potential counterparty risk (ie. the contracting party fails to uphold the terms of the forward contract) by a thorough ex-ante vetting process of credible contractors and potentially contracting risk insurance by a third party as appropriate.

\section{Commodity Exchange Selection}

Based on the concentration of chronically food insecure countries in southern and eastern Africa, the South African Futures Exchange (SAFEX) would be an appropriate place to initiate a hedging pilot. SAFEX was established in 1995 and later was acquired as a separate division of the Johannesburg Stock Exchange (JSE). White and yellow maize, wheat, sunflower seeds, and soybeans are actively traded on the SAFEX derivative and spot markets. Over the last three years (September 2007 - September 2009), monthly option and futures contracts trading on the SAFEX exchange has averaged over 190,000 transactions with an average monthly value of over R25 billion (roughly $\$ 3.4$ billion at current exchange rates ${ }^{19}$ ). Therefore, SAFEX's trading volume values and liquidity could accommodate WFP's operational needs without significantly moving or distorting markets. ${ }^{20}$ Moreover, South Africa already is the largest source country for WFP commodity purchases - totaling over $\$ 160$ million in $2008 .^{21}$

\footnotetext{
${ }^{18}$ Spot market price fluctuations may impact the WFP's ability to offload futures positions. If spot market prices decline, then the seller may encounter difficulties in offloading the futures contract given its relatively unattractive price. Alternatively, increased spot market prices would make the futures contract more attractive and theoretically easier to offload.

${ }^{19} 20$ November 2009 exchange rate of 7.5 South African Rand per U.S. Dollar

${ }^{20} \mathrm{We}$ are aware that basis risk (arising from situations where the spot and futures prices do not converge on the date of expiration of the futures instrument) is an issue when actual delivery is needed, and this can be very large for
} 
Over time, the WFP should consider piloted usage of other regional commodity exchanges to expand the portion of hedged operations. Apart from South Africa, additional candidates worth further exploration include: India, Canada, and Belgium/France (Euronext).

In addition, the WFP's mandate includes: (1) purchasing food from developing countries to the extent possible; and (2) supporting development of local and regional agricultural markets. In this regard, it could partner with leading donor agencies - such as the World Bank Group, African Development Bank Group, FAO, IFAD, USAID, and European Commission - to establish or deepen regional commodity exchanges in developing countries. For example, the recently established Ethiopian Commodity Exchange (ECX) potentially could support WFP operations in the Horn of Africa, Sudan, and East Africa. However, this would require transport infrastructure investments and regulatory reforms to better facilitate regional trade flows. In addition, ECX may need to institute additional policies and reforms to accommodate increased trading volume and WFP standards. The recent G-20 food security initiative could be utilized as a vehicle for driving these broader market development efforts.

\section{$\underline{\text { Revenue Mobilization }}$}

One of the key issues that the WFP needs to consider in tandem with targeted hedging is its financing model. The WFP's operating budget is financed through repeated appeals to donors, targeting specific country or regional needs. It does not receive assessed member dues (like most UN agencies) nor does it have established replenishment cycles covering multiple years (like the World Bank's International Development Association). In other words, WFP funding is extraordinarily reactive in nature - despite the relative macro-level predictability of overall operation levels. Figure 11 shows WFP's own analysis of projected needs vs. funding for the period 2006-2011; we see that funding falls consistently short of program needs by 20 to 30 percent.

small exchanges or where volumes are so small that clearing trades have a price impact. Hence we suggest larger exchanges, such as SAFEX, for the types of transactions that WFP is likely to undertake.

${ }^{21}$ Source: WFP Food Procurement: World View 2008 (online database) 


\section{Figure 11 - Needs Versus Contributions}

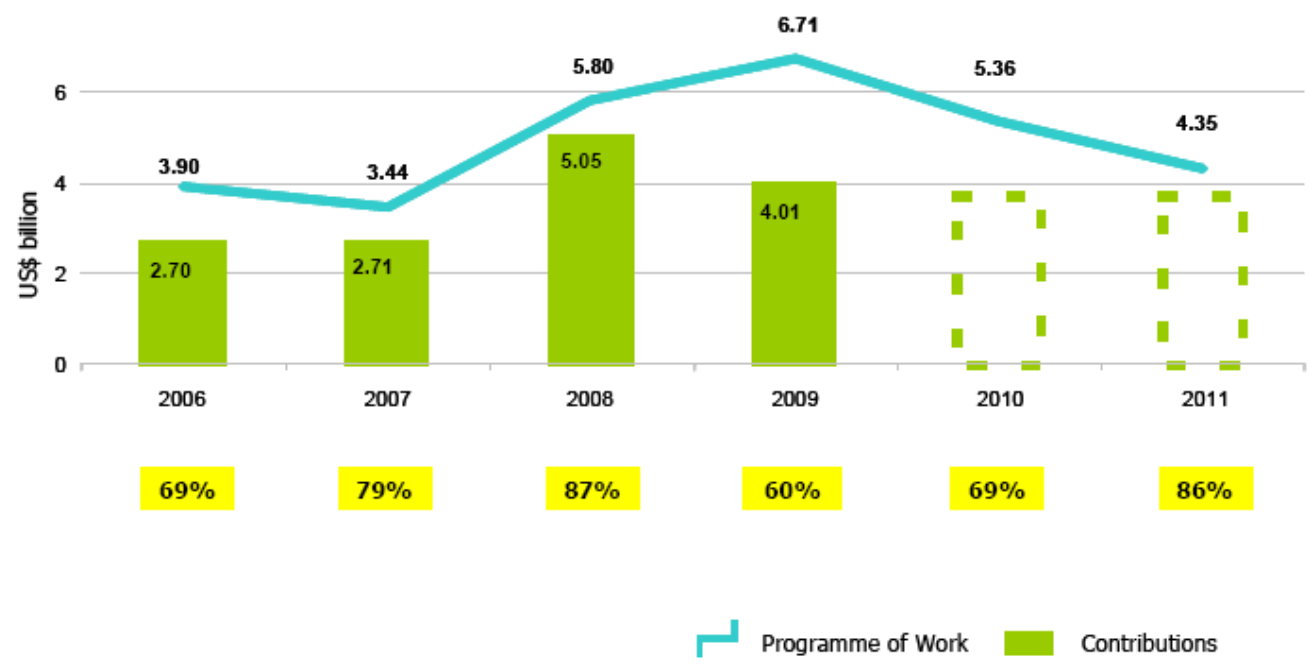

World Food Programme (2010)

Tables 4 and 5 show the levels of funding - disaggregated into direct and unrestricted as well as by individual donors. The United States is the largest WFP contributor by far. Between 2000 and 2009, it provided over $\$ 11$ billion in contributions. The next largest donor - the European Commission - provided just over $\$ 2$ billion. Collectively, the twenty largest WFP donors account for nearly 95 percent of total contributions.

Table 4 - Total Contributions, Direct and Multilateral

\begin{tabular}{|l|r|r|r|r|r|r|r|r|r|r|r|r|r|r|r|r|r|r|r|r|}
\hline Contributions & $\mathbf{2 0 0 1}$ & $\mathbf{2 0 0 2}$ & $\mathbf{2 0 0 3}$ & $\mathbf{2 0 0 4}$ & $\mathbf{2 0 0 5}$ & $\mathbf{2 0 0 6}$ & $\mathbf{2 0 0 7}$ & $\mathbf{2 0 0 8}$ & $\mathbf{2 0 0 9}$ & $\mathbf{2 0 0 0 - 2 0 0 9}$ \\
\hline Total & $\mathbf{1 , 9 0 7}$ & $\mathbf{1 , 8 2 2}$ & $\mathbf{2 , 5 5 5}$ & $\mathbf{2 , 2 4 2}$ & $\mathbf{2 , 7 2 0}$ & $\mathbf{2 , 6 9 9}$ & $\mathbf{2 , 7 1 3}$ & $\mathbf{5 , 0 4 5}$ & $\mathbf{4 , 0 2 6}$ & $\mathbf{2 5 , 9 6 5}$ \\
\hline Direct & 1,534 & 1,471 & 2,271 & 1,962 & 2,441 & 2,457 & 2,457 & 4,158 & 3,705 & 22,677 \\
\hline Multilateral & 373 & 351 & 284 & 280 & 278 & 242 & 257 & 887 & 321 & 3,288 \\
\hline
\end{tabular}

Source: World Food Programme 
Table 5 - Total Contributions by Top 20 WFP Donors, 2000-2009

\begin{tabular}{|c|c|c|c|c|c|c|c|c|c|c|}
\hline $\begin{array}{l}\text { Top } 20 \text { Donors USD } \\
\text { Millions }\end{array}$ & 2001 & 2002 & 2003 & 2004 & 2005 & 2006 & 2007 & 2008 & 2009 & 2000-2009 \\
\hline USA & $1,198.3$ & 938.2 & $1,458.6$ & $1,065.0$ & $1,173.7$ & $1,123.2$ & $1,184.2$ & $2,076.4$ & $1,758.0$ & $11,975.7$ \\
\hline European Commission & 126.8 & 177.3 & 200.9 & 200.5 & 263.9 & 265.8 & 250.4 & 355.4 & 343.8 & $2,184.9$ \\
\hline Canada & 38.5 & 52.7 & 114.7 & 90.0 & 152.5 & 149.4 & 161.4 & 275.4 & 225.3 & $1,259.8$ \\
\hline Japan & 90.6 & 92.9 & 130.1 & 135.7 & 160.5 & 71.4 & 118.9 & 178.2 & 202.7 & $1,181.0$ \\
\hline United Kingdom & 27.7 & 95.7 & 135.7 & 115.9 & 111.6 & 100.4 & 66.9 & 169.0 & 127.6 & 950.4 \\
\hline United Nations Agenci & 0.6 & 0.9 & 1.0 & 0.6 & 7.2 & 159.8 & 143.6 & 217.7 & 216.8 & 748.1 \\
\hline Netherlands & 59.2 & 58.8 & 50.4 & 77.7 & 115.3 & 80.0 & 75.6 & 117.4 & 77.6 & 712.1 \\
\hline Germany & 58.2 & 60.9 & 46.5 & 65.3 & 69.5 & 59.7 & 65.8 & 100.5 & 132.1 & 658.6 \\
\hline Saudi Arabia & 2.2 & 4.2 & 3.3 & 3.3 & 3.3 & 29.7 & 6.5 & 503.8 & 23.3 & 579.7 \\
\hline Australia & 35.5 & 50.4 & 39.2 & 41.5 & 61.9 & 60.6 & 61.8 & 107.9 & 81.4 & 540.2 \\
\hline Sweden & 27.7 & 31.2 & 42.3 & 44.5 & 84.3 & 58.5 & 64.8 & 81.7 & 72.5 & 507.5 \\
\hline Norway & 36.9 & 45.7 & 51.4 & 54.9 & 93.8 & 51.3 & 40.7 & 53.5 & 40.4 & 468.5 \\
\hline Spain & 4.0 & 2.6 & 6.8 & 17.5 & 11.6 & 17.0 & 29.6 & 116.9 & 213.9 & 419.8 \\
\hline Private Donors & 5.9 & 4.8 & 5.7 & 21.7 & 27.1 & 55.0 & 49.2 & 143.8 & 104.4 & 417.7 \\
\hline Denmark & 39.8 & 40.2 & 39.3 & 43.4 & 53.2 & 43.8 & 44.7 & 56.5 & 41.9 & 402.8 \\
\hline Italy & 39.7 & 41.8 & 41.1 & 47.9 & 45.8 & 12.4 & 31.5 & 101.7 & 30.0 & 391.9 \\
\hline Switzerland & 19.2 & 24.2 & 30.9 & 32.7 & 35.7 & 33.5 & 32.0 & 45.7 & 39.1 & 292.8 \\
\hline France & 36.0 & 14.5 & 14.9 & 30.4 & 37.8 & 25.3 & 32.1 & 40.5 & 23.4 & 254.8 \\
\hline Finland & 14.4 & 17.4 & 17.8 & 18.0 & 23.8 & 18.3 & 25.6 & 28.3 & 28.5 & 192.0 \\
\hline Ireland & 7.3 & 10.3 & 11.8 & 13.7 & 19.8 & 31.0 & 34.4 & 39.8 & 22.5 & 190.8 \\
\hline Total & $1,868.34$ & $1,764.72$ & $2,442.56$ & $2,120.36$ & $2,552.17$ & $2,446.00$ & $2,519.56$ & $4,810.15$ & $3,805.18$ & $24,329.05$ \\
\hline$\%$ of WFP Total & $98 \%$ & $97 \%$ & $96 \%$ & $95 \%$ & $94 \%$ & $91 \%$ & $93 \%$ & $95 \%$ & $95 \%$ & $95 \%$ \\
\hline
\end{tabular}

\section{Source: World Food Programme}

The majority of donor contributions remain provided through in-kind transfers or restricted to specific WFP programs. Both forms of contributions meet critical purposes - both in terms of assisting vulnerable populations as well as maintaining political support in the host country, such as with the U.S. Congress. However, in-kind transfers also pass commodity price risks along to the WFP and end-beneficiaries. Legislative bodies typically agree to provide a set monetary value of in-kind food transfers in any given year (ex - \$100 million). If prices rise before the transfers are provided to the WFP, then that legislative appropriation will purchase less food on local markets. In turn, the WFP will have fewer in-kind food stocks to meet operational requirements. The WFP could encourage donors to address these price risks through two channels: (1) make in-kind transfer commitments in metric tonnage terms (versus monetary values); or (2) continue monetary value commitments, but also enter into forward contracts to lock-in specific food volume deliveries. The latter option may be politically attractive to some donors since it will provide greater price predictability for domestic farmers.

Between 2000 and 2009, annual "multilateral" contributions averaged to about 13 percent of total contribution levels. ${ }^{22}$ This reflects both donor preferences and the WFP's reactive resource appeals process. In recent years, the WFP has made significant efforts to solicit unrestricted resources and has achieved good results. The largest providers of unrestricted resources have been Saudi Arabia, Sweden, the Netherlands, Denmark, Norway, Germany, and Canada. The

\footnotetext{
${ }^{22}$ The WFP uses the term "multilateral" for cash contributions that contain no usage restrictions.
} 
WFP has also actively pursued relationships with the private sector, reaching agreements with LG Electronics, Heinz, and Kraft Foods that will help WFP to achieve its goals (WFP, 2010).

For the past two fiscal years, the United States has made cash resources available for local regional purchases (LRP) and plans to do so again this fiscal year. Under the President's supplemental call (FY08 Supplemental Appropriations Act P.L.

110-252) for increased foreign aid to assist populations affected by high food prices, the U.S. Congress approved an exceptional injection of cash funds totaling \$165 million. The WFP received about $\$ 82$ million of these funds for local regional purchases and another $\$ 29$ million for other activities. Although earmarked for specific programs, these extra funds were nonetheless useful to WFP's ability to respond to high food prices.

In a document prepared for its Board, the WFP recognizes the challenges of climate change, conflict, and volatile food and fuel prices and concludes that it needs to explore "new, complementary sources" of funding. It also asks the Board to "advocate for untied funding that brings maximum flexibility and predictability, particularly through multi-year cash contributions...." (WFP, 2010, p. 4). Table 6 shows the amounts of unrestricted contributions for the past decade, while Table 7 looks at the share of these funds that are multi-year contributions.

Table 6 - Unrestricted Cash Contributions by Top 20 WFP Donors, 2000-2009

\begin{tabular}{|c|c|c|c|c|c|c|c|c|c|c|}
\hline $\begin{array}{l}\text { Top } 20 \text { Donors, } \\
\text { Unrestricted } \\
\text { Component (USD } \\
\text { Millions) }\end{array}$ & 2001 & 2002 & 2003 & 2004 & 2005 & 2006 & 2007 & 2008 & 2009 & 2000-2009 \\
\hline USA & 183.1 & 154.3 & 82.0 & 54.3 & 31.0 & & & & & 504.6 \\
\hline \multicolumn{2}{|l|}{ European Commission } & & 0.2 & & & & & & & 0.2 \\
\hline Canada & 22.8 & 22.6 & 28.3 & 20.9 & 19.6 & 27.2 & 22.9 & 33.6 & 26.3 & 224.1 \\
\hline Japan & 12.7 & 8.1 & 9.2 & 16.9 & 7.5 & 5.3 & 5.2 & 5.4 & 4.9 & 75.1 \\
\hline United Kingdom & 0.3 & 0.5 & & & & 0.7 & & 0.2 & 0.5 & 2.2 \\
\hline United Nations Ag€ & 0.0 & & & 0.1 & & & 0.1 & 0.0 & & 0.2 \\
\hline Netherlands & 25.5 & 24.0 & 28.4 & 33.2 & 36.0 & 33.8 & 35.6 & 52.5 & 53.7 & 322.7 \\
\hline Germany & 6.9 & 20.9 & 24.0 & 28.6 & 29.2 & 31.2 & 30.8 & 31.2 & 34.5 & 237.4 \\
\hline Saudi Arabia & & 3.2 & & & & & & 500.0 & 0.0 & 503.2 \\
\hline Australia & 22.3 & 12.8 & & & 0.0 & 3.8 & & 9.6 & & 48.5 \\
\hline Sweden & 20.9 & 24.3 & 27.6 & 38.8 & 59.9 & 51.1 & 56.8 & 72.1 & 58.5 & 409.9 \\
\hline Norway & 24.7 & 30.7 & 30.3 & 30.6 & 33.6 & 30.9 & 25.0 & 28.4 & 29.7 & 264.0 \\
\hline Spain & 1.8 & & & & & & 7.3 & 27.6 & 25.7 & 62.4 \\
\hline Private Donors & 0.0 & & 0.8 & 0.0 & 0.9 & 0.0 & 2.1 & 3.9 & 2.4 & 10.1 \\
\hline Denmark & 30.6 & 27.5 & 27.7 & 31.4 & 35.1 & 32.5 & 35.1 & 46.5 & 34.8 & 301.2 \\
\hline Italy & 5.0 & 8.8 & 5.2 & 7.2 & 5.9 & 0.0 & 6.6 & 20.9 & 13.3 & 72.8 \\
\hline Switzerland & 1.5 & 2.2 & 2.9 & 2.0 & 2.5 & 2.5 & 1.6 & 3.8 & 2.7 & 21.8 \\
\hline France & 0.7 & 0.1 & & 1.7 & 0.4 & 0.2 & 0.6 & 0.5 & 0.1 & 4.4 \\
\hline Finland & 8.4 & 8.4 & 8.4 & 7.4 & 7.8 & 7.2 & 8.1 & 9.7 & 10.9 & 76.3 \\
\hline Ireland & 3.1 & 3.8 & 6.0 & 2.2 & 2.0 & 9.2 & 11.6 & 20.2 & 12.7 & 70.9 \\
\hline Total & 370.3 & 352.3 & 281.0 & 275.2 & 271.4 & 235.7 & 249.4 & 866.2 & 310.6 & 3211.99 \\
\hline Unrestricted Total & $20 \%$ & $20 \%$ & $12 \%$ & $13 \%$ & $11 \%$ & $10 \%$ & $10 \%$ & $18 \%$ & $8 \%$ & $13 \%$ \\
\hline
\end{tabular}

Source: World Food Programme

Multi-year commitments totaled $\$ 279$ million (out of $\$ 10.5$ billion) between 2006 and 2008 (see figure 15); about 3 percent of total WFP donor contributions during this period. If United States' 
commitments under the McGovern-Dole program are excluded ${ }^{23}$, the percentage of multi-year commitments drops to less than 2 percent of total donor contributions. Multi-year cash contribution commitments have increased on a relative basis in recent years; this is critical to WFP's ability to purchase food using forward markets. Appendix II describes donor contributions in more detail.

Table 7- Multi-year Donor Commitments, 2005-2013

\begin{tabular}{|l|r|r|r|r|r|r|r|r|r|}
\hline Donor (USD) & $\mathbf{2 0 0 5}$ & $\mathbf{2 0 0 6}$ & \multicolumn{1}{c|}{$\mathbf{2 0 0 7}$} & \multicolumn{1}{c|}{$\mathbf{2 0 0 8}$} & \multicolumn{1}{c|}{$\mathbf{2 0 0 9}$} & $\mathbf{2 0 1 0}$ & $\mathbf{2 0 1 1}$ & $\mathbf{2 0 1 2}$ & $\mathbf{2 0 1 3}$ \\
\hline AUSTRALIA & & & & & & 39.301 & 39.301 & 39.301 & 39.301 \\
\hline AUSTRALIA & & & & 0.508 & 0.508 & 0.508 & & & \\
\hline AUSTRALIA & & & & 0.247 & 0.247 & & & & \\
\hline CANADA & & & 23.585 & 23.585 & 23.585 & 23.585 & 23.585 & & \\
\hline ICELAND & & & 1.603 & 1.603 & & & & & \\
\hline LUXEMBOURG & & & & & 0.291 & 0.291 & 0.291 & & \\
\hline LUXEMBOURG & & & 3.325 & 6.243 & 8.016 & 7.375 & & & \\
\hline NETHERLANDS & & & 35.314 & 35.314 & 35.268 & & & & \\
\hline UK ** & 8.897 & 4.448 & 8.897 & 4.448 & & & & & \\
\hline RUSSIAN FEDERATION & & & 15.000 & 15.000 & 15.000 & & & & \\
\hline USA & & & 50.000 & 50.000 & 50.000 & 50.000 & 50.000 & & \\
\hline Total & $\mathbf{8 . 8 9 7}$ & $\mathbf{4 . 4 4 8}$ & $\mathbf{1 3 7 . 7 2 4}$ & $\mathbf{1 3 6 . 9 4 8}$ & $\mathbf{1 3 2 . 9 1 5}$ & $\mathbf{1 2 1 . 0 6 0}$ & $\mathbf{1 1 3 . 1 7 7}$ & $\mathbf{3 9 . 3 0 1}$ & $\mathbf{3 9 . 3 0 1}$ \\
\hline
\end{tabular}

Source: WFP and author calculations; the numbers highlighted in green represent commitments that potentially could support long-term financial management transactions and the numbers highlighted in yellow represent inkind commitments provided by the United States through the McGovern-Dole program. Data as of October 2009.

\footnotetext{
${ }^{23}$ The McGovern-Dole International Food for Education and Child Nutrition Program (IFEP) is a food assistance program in the United States, authorized in the 2002 Farm Bill (P.L. 107-171, Sec. 3107) which provides for the donation of U.S. agricultural commodities and associated financial and technical assistance to carry out preschool and school feeding programs in foreign countries. Maternal, infant and child nutrition programs also are authorized under this program. The program was first implemented in FY2003 with $\$ 100$ million of Commodity Credit Corporation funds as stipulated in the 2002 farm bill. Beginning in FY2004, the authorizing statute provides for the program to be carried out with appropriated funding. The FY2004 agricultural appropriations act (P.L. 108-199) provided $\$ 50$ million to carry out the program. IFPED began in FY2000 as a pilot project and was called Global Food for Education Initiative (GFEI). It used the donation of surplus agricultural commodities under Section 416 of the Agricultural Act of 1949 (P.L. 89-439, as amended) to support a global school feeding program (wikipedia.org, based on a publication entitled Agriculture: A Glossary of Terms, Programs, and Laws, 2005 Edition by Jasper Womach at the Congressional Research Service).
} 


\section{$\underline{\text { Financial Backstop Options }}$}

The hedging strategies proposed in this paper would entail entrance into financial commitments up to one-year in the future at the very least. Our analysis reinforces the WFP's argument that its board must revise its cash-in, cash-out operating model - with modest multi-year donor contribution commitments - to increase its ability to execute hedging activities of a mediumterm and possibly even short-term nature. The increase in the share of multi-year, unrestricted cash contributions to the WFP in the last few years is a welcome step in the right direction. In particular, Canada has made unrestricted contributions of $\$ 24$ million per year for the past few years. The Australian government also has recently announced multi-year cash contributions to the WFP of almost $\$ 40$ million for each of the next 5 years. These resources will enable the WFP to expand its financial options, including developing a hedging strategy to cope with price fluctuations.

The WFP may also need to explore financial backstop options to ensure compliance with internal financial management policies. Commodity exchange regulations or forward contract counterparties may also stipulate margin requirements or minimum collateral levels. Clearly, the most ideal solution is to improve the institution's financial foundation through: (1) legally binding multi-year donor commitments; (2) greater predictability of annual donor contributions; and (3) unrestricted financial contributions. While several donors have moved in this direction such as Australia, the Netherlands, and Luxembourg - their related commitment levels still account for a very modest portion of total WFP donor contributions. We include several financial backstop options below for consideration that could be implemented independently or in tandem. Ultimately, the WFP would need to complete cost-benefit analysis on each option to determine the most appropriate approach.

- Commercial Line of Credit: The WFP could establish a credit line facility with a leading international commercial bank (ex - Standard Chartered, Standard Bank, BNP Paribas). To address credit risk issues and potential WFP Board concerns, the facility size would be a modest portion of average annual WFP operations. In addition, the credit line would only be tapped prudently as a last resort to address: (1) hedging collateral requirements if required or (2) short-term inter-temporal mismatches between contributions and food operations.

- International Financial Institution Guarantee: Alternatively, the WFP could negotiate a credit guarantee arrangement with the World Bank or African Development Bank. As of end-June 2009, the World Bank had liquid investments (separate from loan operations) totaling over $\$ 41$ billion. ${ }^{24}$ As sister development institutions, they may be an appropriate partner. However, World Bank and African Development Bank shareholders likely will be hesitant to provide this support due to precedent and financial management concerns.

- Bilateral Donor Credit Line: A third option would entail an individual or group of bilateral donors providing a credit line, guarantee, and/or flexible advance contributions as needed to support WFP hedging operations.

\footnotetext{
${ }^{24}$ International Bank for Reconstruction and Development, 2009 Financial Statement, p46.
} 


\section{CONCLUSION}

While food prices have declined slightly since 2008, they are still relatively high. On top of this, the world's poor have had to deal with the effects of a global recession. It is imperative that rich countries do better in terms of delivering food assistance to the world's poorest people. In this paper, we have outlined ways in which donors can commit to feeding the poor and financial mechanisms that will enable more food to reach more people around the world. 


\section{REFERENCES}

Aker, Jenny. "Toward Measuring the Impact of the World Food Program's Purchase for Progress Initiative". Center for Global Development, Washington DC, December 2008.

Clay, Edward J. 2003. 'Responding to change: WFP and the global food aid system.' Development Policy Review 21(5): 697-709.

Elliott, Kimberly Ann. "Biofuels and the Food Price Crisis: A Survey of the Issues". Center for Global Development, Working Paper 151. Washington DC, August 2008.

Geyser, M. and M. Cutts. 2007. "SAFEX maize price volatility scruntinised." Agrekon, Vol 46, No 3 (September 2007).

Lustig, Nora. "Coping with Rising Food Prices: Policy Dilemmas in the Developing World" Center for Global Development, Working Paper 164. Washington DC, March 2009.

Milken Institute. "Feeding the World's Hungry: Fostering an efficient and Responsive Food Access Pipeline." Milken Institute Financial Lab Reports, October 21, 2009, Santa Monica, CA.

Slater, Rachel and Julie Dana, "Tackling vulnerability to hunger in Malawi through marketbased options contracts," Humanitarian Exchange Magazine, Issue 33, April 2006.

Sheeran, Josette. "The New Face of Hunger." Presentation at the Peterson Institute, May 2008.

Timmer, Peter. "The Causes of High Food Prices," Chapter 2.3 in Asian Development Outlook Update, (September, 2008) Asian Development Bank, Manila, Philippines, pp 72-93.

U.S. Dept of State, 2009 "Global Hunger and Food Security Initiative". Consultation Document. http://www.state.gov/s/globalfoodsecurity/129952.htm

World Bank. "Rising Food and Fuel Prices: Addressing the Risks to Future Generations." Human Development Network and Poverty Reduction and Economic Management Network. The World Bank. October 12, 2008

World Food Programme website, www.wfp.org

World Food Programme, “ Business Process Review: Working-Capital Financing,” Resource, Financial and Budgetary Matters, January 2005.

World Food Programme "Food Procurement in Developing Countries", World Food Programme Policy Paper, October 2006. Available at www.wfp.org

World Food Programme "Resources for a Changing Environment", Policy Issues Agenda Item 5, February 2010 Available at www.wfp.org 
Zoellick, Robert B. "A Challenge of Economic Statecraft." Speech at the Center for Global Development. April 2, 2008. 
Appendix I

\section{WFP Operations - Select Countries, 2001-2009}

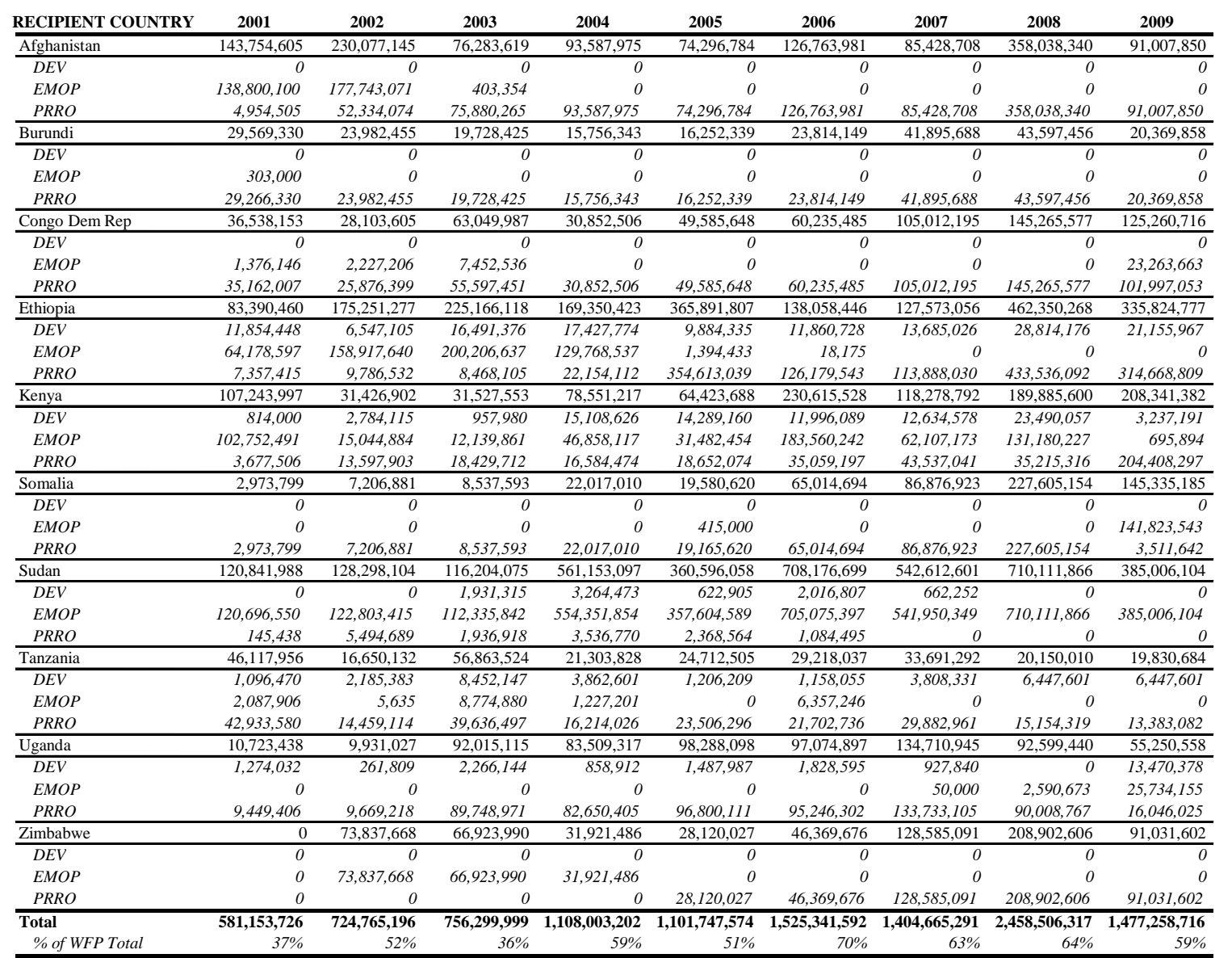

SUMMARY STATISTICS

\begin{tabular}{|c|c|c|c|c|c|c|}
\hline \multirow[b]{2}{*}{ Median } & \multirow[b]{2}{*}{ Min } & \multirow[b]{2}{*}{ Max } & \multirow[b]{2}{*}{ STDEV } & \multicolumn{3}{|c|}{ Confidence Interval } \\
\hline & & & & $90 \%$ & $95 \%$ & $99 \%$ \\
\hline $93,587,975$ & $74,296,784$ & $358,038,340$ & $94,678,268$ & $3,965,800$ & $1,978,990$ & 395,549 \\
\hline 0 & 0 & 0 & & & & \\
\hline 0 & 0 & $177,743,071$ & $70,441,955$ & & & \\
\hline $85,428,708$ & $4,954,505$ & $358,038,340$ & $99,844,469$ & & & \\
\hline $23,814,149$ & $15,756,343$ & $43,597,456$ & $10,336,880$ & 432,982 & 216,064 & 43,186 \\
\hline 0 & 0 & 0 & & & & \\
\hline 0 & 0 & 303,000 & 101,000 & & & \\
\hline $23,814,149$ & $15,756,343$ & $43,597,456$ & $10,324,682$ & & & \\
\hline $60,235,485$ & $28,103,605$ & $145,265,577$ & $43,143,585$ & $1,807,160$ & 901,798 & 180,246 \\
\hline 0 & 0 & 0 & & & & \\
\hline 0 & 0 & $23,263,663$ & $7,687,021$ & & & \\
\hline $55,597,451$ & $25,876,399$ & $145,265,577$ & $40,744,463$ & & & \\
\hline $175,251,277$ & $83,390,460$ & $462,350,268$ & $127,853,331$ & $5,355,407$ & $2,672,423$ & 534,149 \\
\hline $13,685,026$ & $6,547,105$ & $28,814,176$ & $6,662,612$ & & & \\
\hline $1,394,433$ & 0 & $200,206,637$ & $80,728,582$ & & & \\
\hline $113,888,030$ & $7,357,415$ & $433,536,092$ & $168,614,008$ & & & \\
\hline $107,243,997$ & $31,426,902$ & $230,615,528$ & $75,436,912$ & $3,159,835$ & $1,576,802$ & 315,162 \\
\hline $11,996,089$ & 814,000 & $23,490,057$ & $7,897,034$ & & & \\
\hline $46,858,117$ & 695,894 & $183,560,242$ & $61,995,138$ & & & \\
\hline $18,652,074$ & $3,677,506$ & $204,408,297$ & $61,726,319$ & & & \\
\hline $22,017,010$ & $2,973,799$ & $227,605,154$ & $77,183,653$ & $3,233,001$ & $1,613,313$ & 322,460 \\
\hline 0 & 0 & 0 & & & & \\
\hline 0 & 0 & $141,823,543$ & $47,257,422$ & & & \\
\hline $19,165,620$ & $2,973,799$ & $227,605,154$ & $73,126,750$ & & & \\
\hline $385,006,104$ & $116,204,075$ & $710,111,866$ & $242,744,374$ & $10,167,862$ & $5,073,906$ & $1,014,143$ \\
\hline 622,905 & 0 & $3,264,473$ & $1,186,240$ & & & \\
\hline $385,006,104$ & $112,335,842$ & $710,111,866$ & $243,111,346$ & & & \\
\hline $1,084,495$ & 0 & $5,494,689$ & $1,926,210$ & & & \\
\hline $24,712,505$ & $16,650,132$ & $56,863,524$ & $13,590,780$ & 569,279 & 284,078 & 56,780 \\
\hline $3,808,331$ & $1,096,470$ & $8,452,147$ & $2,721,805$ & & & \\
\hline 5,635 & 0 & $8,774,880$ & $3,268,108$ & & & \\
\hline $21,702,736$ & $13,383,082$ & $42,933,580$ & $11,099,781$ & & & \\
\hline $92,015,115$ & $9,931,027$ & $134,710,945$ & $41,865,999$ & $1,753,646$ & 875,094 & 174,909 \\
\hline $1,274,032$ & 0 & $13,470,378$ & $4,180,378$ & & & \\
\hline 0 & 0 & $25,734,155$ & $8,511,036$ & & & \\
\hline $89,748,971$ & $9,449,406$ & $133,733,105$ & $45,525,041$ & & & \\
\hline $66,923,990$ & 0 & $208,902,606$ & $62,871,881$ & $2,633,522$ & $1,314,164$ & 262,668 \\
\hline 0 & 0 & 0 & & & & \\
\hline 0 & 0 & $73,837,668$ & $30,896,053$ & & & \\
\hline $28,120,027$ & 0 & $208,902,606$ & $73,560,300$ & & & \\
\hline $237,526,846$ & $581,153,726$ & $\overline{2,458,506,317}$ & $572,229,922$ & & & \\
\hline
\end{tabular}

Source: World Food Programme 
Donor Contribution Levels, 2000-2009

Appendix II

\begin{tabular}{|c|c|c|c|c|c|c|c|c|c|}
\hline Contributions & 2001 & 2002 & 2003 & 2004 & 2005 & 2006 & 2007 & 2008 & 2009 \\
\hline Total & $1,906,654,951$ & $1,821,640,670$ & $2,555,114,627$ & $2,242,022,913$ & $2,719,500,611$ & $2,698,851,141$ & $2,713,422,114$ & $5,044,788,517$ & $4,025,842,271$ \\
\hline Direct & $1,534,138,244$ & $1,470,761,947$ & $2,271,224,409$ & $1,962,040,672$ & $2,441,421,785$ & $2,457,121,560$ & $2,456,808,489$ & $4,158,111,388$ & $3,704,861,763$ \\
\hline Multilateral & $372,516,707$ & $350,878,723$ & $283,890,218$ & $279,982,241$ & $278,078,826$ & $241,729,581$ & $256,613,625$ & $886,677,129$ & $320,980,508$ \\
\hline Top 20 Donors & & & & & & & & & \\
\hline USD Millions & 2001 & 2002 & 2003 & 2004 & 2005 & 2006 & 2007 & 2008 & 2009 \\
\hline USA & $1,198.3$ & 938.2 & $1,458.6$ & $1,065.0$ & $1,173.7$ & $1,123.2$ & $1,184.2$ & $2,076.4$ & $1,758.0$ \\
\hline European Commissi & 126.8 & 177.3 & 200.9 & 200.5 & 263.9 & 265.8 & 250.4 & 355.4 & 343.8 \\
\hline Canada & 38.5 & 52.7 & 114.7 & 90.0 & 152.5 & 149.4 & 161.4 & 275.4 & 225.3 \\
\hline Japan & 90.6 & 92.9 & 130.1 & 135.7 & 160.5 & 71.4 & 118.9 & 178.2 & 202.7 \\
\hline United Kingdom & 27.7 & 95.7 & 135.7 & 115.9 & 111.6 & 100.4 & 66.9 & 169.0 & 127.6 \\
\hline United Nations Ag $\epsilon$ & 0.6 & 0.9 & 1.0 & 0.6 & 7.2 & 159.8 & 143.6 & 217.7 & 216.8 \\
\hline Netherlands & 59.2 & 58.8 & 50.4 & 77.7 & 115.3 & 80.0 & 75.6 & 117.4 & 77.6 \\
\hline Germany & 58.2 & 60.9 & 46.5 & 65.3 & 69.5 & 59.7 & 65.8 & 100.5 & 132.1 \\
\hline Saudi Arabia & 2.2 & 4.2 & 3.3 & 3.3 & 3.3 & 29.7 & 6.5 & 503.8 & 23.3 \\
\hline Australia & 35.5 & 50.4 & 39.2 & 41.5 & 61.9 & 60.6 & 61.8 & 107.9 & 81.4 \\
\hline Sweden & 27.7 & 31.2 & 42.3 & 44.5 & 84.3 & 58.5 & 64.8 & 81.7 & 72.5 \\
\hline Norway & 36.9 & 45.7 & 51.4 & 54.9 & 93.8 & 51.3 & 40.7 & 53.5 & 40.4 \\
\hline Spain & 4.0 & 2.6 & 6.8 & 17.5 & 11.6 & 17.0 & 29.6 & 116.9 & 213.9 \\
\hline Private Donors & 5.9 & 4.8 & 5.7 & 21.7 & 27.1 & 55.0 & 49.2 & 143.8 & 104.4 \\
\hline Denmark & 39.8 & 40.2 & 39.3 & 43.4 & 53.2 & 43.8 & 44.7 & 56.5 & 41.9 \\
\hline Italy & 39.7 & 41.8 & 41.1 & 47.9 & 45.8 & 12.4 & 31.5 & 101.7 & 30.0 \\
\hline Switzerland & 19.2 & 24.2 & 30.9 & 32.7 & 35.7 & 33.5 & 32.0 & 45.7 & 39.1 \\
\hline France & 36.0 & 14.5 & 14.9 & 30.4 & 37.8 & 25.3 & 32.1 & 40.5 & 23.4 \\
\hline Finland & 14.4 & 17.4 & 17.8 & 18.0 & 23.8 & 18.3 & 25.6 & 28.3 & 28.5 \\
\hline Ireland & 7.3 & 10.3 & 11.8 & 13.7 & 19.8 & 31.0 & 34.4 & 39.8 & 22.5 \\
\hline Total & $1,868.34$ & $1,764.72$ & $2,442.56$ & $2,120.36$ & $2,552.17$ & $2,446.00$ & $2,519.56$ & $4,810.15$ & $3,805.18$ \\
\hline$\%$ of WFP Total & $98 \%$ & $97 \%$ & $96 \%$ & $95 \%$ & $94 \%$ & $91 \%$ & $93 \%$ & $95 \%$ & $95 \%$ \\
\hline
\end{tabular}




\begin{tabular}{|c|c|c|c|c|c|c|c|c|c|}
\hline $\begin{array}{l}\text { Top } 20 \text { Donors, } \\
\text { Unrestricted } \\
\text { Component (USD } \\
\text { Millions) }\end{array}$ & 2001 & 2002 & 2003 & 2004 & 2005 & 2006 & 2007 & 2008 & 2009 \\
\hline USA & 183.1 & 154.3 & 82.0 & 54.3 & 31.0 & & & & \\
\hline \multicolumn{2}{|l|}{ European Commission } & & 0.2 & & & & & & \\
\hline Canada & 22.8 & 22.6 & 28.3 & 20.9 & 19.6 & 27.2 & 22.9 & 33.6 & 26.3 \\
\hline Japan & 12.7 & 8.1 & 9.2 & 16.9 & 7.5 & 5.3 & 5.2 & 5.4 & 4.9 \\
\hline United Kingdom & 0.3 & 0.5 & & & & 0.7 & & 0.2 & 0.5 \\
\hline United Nations Ag $\epsilon$ & 0.0 & & & 0.1 & & & 0.1 & 0.0 & \\
\hline Netherlands & 25.5 & 24.0 & 28.4 & 33.2 & 36.0 & 33.8 & 35.6 & 52.5 & 53.7 \\
\hline Germany & 6.9 & 20.9 & 24.0 & 28.6 & 29.2 & 31.2 & 30.8 & 31.2 & 34.5 \\
\hline Saudi Arabia & & 3.2 & & & & & & 500.0 & 0.0 \\
\hline Australia & 22.3 & 12.8 & & & 0.0 & 3.8 & & 9.6 & \\
\hline Sweden & 20.9 & 24.3 & 27.6 & 38.8 & 59.9 & 51.1 & 56.8 & 72.1 & 58.5 \\
\hline Norway & 24.7 & 30.7 & 30.3 & 30.6 & 33.6 & 30.9 & 25.0 & 28.4 & 29.7 \\
\hline Spain & 1.8 & & & & & & 7.3 & 27.6 & 25.7 \\
\hline Private Donors & 0.0 & & 0.8 & 0.0 & 0.9 & 0.0 & 2.1 & 3.9 & 2.4 \\
\hline Denmark & 30.6 & 27.5 & 27.7 & 31.4 & 35.1 & 32.5 & 35.1 & 46.5 & 34.8 \\
\hline Italy & 5.0 & 8.8 & 5.2 & 7.2 & 5.9 & 0.0 & 6.6 & 20.9 & 13.3 \\
\hline Switzerland & 1.5 & 2.2 & 2.9 & 2.0 & 2.5 & 2.5 & 1.6 & 3.8 & 2.7 \\
\hline France & 0.7 & 0.1 & & 1.7 & 0.4 & 0.2 & 0.6 & 0.5 & 0.1 \\
\hline Finland & 8.4 & 8.4 & 8.4 & 7.4 & 7.8 & 7.2 & 8.1 & 9.7 & 10.9 \\
\hline Ireland & 3.1 & 3.8 & 6.0 & 2.2 & 2.0 & 9.2 & 11.6 & 20.2 & 12.7 \\
\hline Total & 370.3 & 352.3 & $281.0^{\prime}$ & 275.2 & 271.4 & 235.7 & 249.4 & 866.2 & 310.6 \\
\hline Unrestricted Total & $20 \%$ & $20 \%$ & $12 \%$ & $13 \%$ & $11 \%$ & $10 \%$ & $10 \%$ & $18 \%$ & $8 \%$ \\
\hline
\end{tabular}

Source: World Food Programme 


\section{Local Procurement}

While beyond the scope of this paper, it is also worth considering the impact of local procurement of food, especially in light of price fluctuations. In a provocative essay published last year, economist Jenny Aker raises some important questions around the WFP's Purchase for Progress (P4P) program (Aker, 2008). While donors and international organizations have been purchasing food in recipient countries for years, this idea has got a new boost with the Purchase for Progress (P4P) initiative. The idea is simple: rather than import food from the U.S. or Europe, the WFP will purchase food commodities from local farmers to distribute within the same country or region. Aker asks whether purchasing food locally the answer to higher global food prices, to the inefficiencies associated with imported food aid, and to farmers' low incomes.

Aker questions some key assumptions of the P4P, namely that farmers do not have access to markets, that establishing a parallel sales mechanism is an effective and sustainable means of increasing farm-gate prices, that such purchases will have a minimal impact on consumers' prices, and that higher farm-gate prices in the short-term will serve as a sufficient incentive for farmers to increase production in the long-term. She outlines three scenarios regarding the impact on consumer prices (Aker, 2008, p.3-4):

Local purchases-whether bought from traders or farmers-can change market participants' behavior and hence supply, demand, and prices. The nature of this effect (positive or negative) and its magnitude depend upon the country-specific situation and the location, quantity, and purchase price of the procurement (Beekhuis 2008). A few scenarios are possible:

- Scenario \#1: Minimal impact on consumer prices. Local procurements are unlikely to have a significant and sustained impact on prices if markets are well integrated and supply is highly elastic.

- Scenario \#2: Upward pressure on consumer prices. If markets are well integrated but supply is relatively inelastic, local procurement is likely to exert an upward pressure on consumer prices. In this case, local food procurement and distribution will lead to a transfer of resources from net-deficit households (who do not benefit from the aid) to surplus households and food aid beneficiaries.

- Scenario \#3: Ambiguous effect. If markets are not integrated well enough to transmit changes in prices from one market to another, local procurement may increase consumer prices in surplus zones but not necessarily in deficit zones.

Aker suggests that WFP and its donors measure its impact on a variety of groups in the short-and medium-term, in order to ensure that it is not doing (undue) harm and to identify the conditions under which it will work effectively. 